\title{
SOSIALISASI PENJERNIH AIR KOMPOSIT KARBON AKTIF (KOMAK) UNTUK MEMPEROLEH AIR LAYAK PAKAI KEPADA MASYARAKAT PAGUTAN BARAT
}

\author{
Siti Alaa ${ }^{1 *}$, Iwan Sumarlan², Susi Rahayu ${ }^{1}$ Dian W. Kurniawidi ${ }^{1}$ \\ ${ }^{1}$ Program Studi Fisika, Fakultas MIPA, Universitas Mataram \\ 2Program Studi Kimia, Fakultas MIPA, Universitas Mataram \\ ${ }^{*}$ Corresponding author :siti.alaa@unram.ac.id
}

\begin{abstract}
ABSTRAK. Masyarakat Pagutan Barat sebagian besar warganya mengalami trauma terhadap gempa Lombok 2018. Selain trauma, air PDAM yang mengalir mengalami kekeruhan selama beberapa bulan sehingga tidak dapat digunakan untuk kebersihan sehari-hari. Diperlukan suatu teknologi sederhana berupa penjernihan air agar warga dapat memanfaatkan air PDAM. Salah satu metode penjernihan air yang sederhana dan efektif adalah dengan menggunakan komposit karbon aktif (KOMAK). Karbon aktif merupakan absorben yang baik untuk menyerap polutan organik dan anorganik, senyawa-senyawa berbahaya dan bau dari air. Disamping itu, masyarakat Pagutan Barat perlu diberi edukasi pemanfaatan air yang tercemar menjadi air layak pakai sebelum air tersebut dijernihkan menggunakan alat penjernih air KOMAK. Oleh karena itu setelah dilakukan pembuatan komposit karbon aktif, diberikan juga pendampingan pembuatan prototipe alat perjernih air KOMAK sehingga prototipe ini dapat dikembangkan sendiri oleh masyarakat untuk memperoleh air layak pakai.
\end{abstract}

Kata Kunci: air tercemar, komposit karbon aktif, penjernih air.

ABSTRACT. The West Pagutan citizens, were traumatized by the 2018 Lombok earthquake. Aside from trauma, the flowing PDAM water experienced turbidity for several months so that it could not be used for daily uses. A simple technology is needed like water purification so that residents can use PDAM water again. The simple and effective water purification method is to use an activated carbon composite (KOMAK). Activated carbon is a good absorbent for absorbing organic and inorganic pollutants, harmful compounds and odors from water. Beside that, the West Pagutan citizens needs to be educated that polluted water must filter into suitable water using water purifier before they use it. Therefore, after making an activated carbon composite, assistance was also provided to make KOMAK water purification equipment so that this prototype could be developed by the community to obtain hygine water.

Keywords: activated carbon composite, polluted water, water purification. 
PENDAHULUAN Lingkungan Pagutan Barat merupakan salah satu bagian dari wilayah Kecamatan Mataram Kota Mataram yang terdampak gempa Lombok 2018. Air dari Perusahaan Daerah Air Minum (PDAM) Giri Menang Mataram, Lombok, Nusa Tenggara Barat, keruh akibat gempa bumi 7 skala richter (SR) yang terjadi pada Minggu malam bulan Agustus di wilayah tersebut. Warga Kota Mataram terpaksa memanfaatkan air sungai dan air sumur untuk kebutuhan memasak, mencuci dan mandi. Dengan kondisi air seperti itu, warga yang tidak memiliki sumur terpaksa turun ke sungai mengambil air bersih untuk kebutuhan memasak, mencuci dan mandi. Direktur Utama PDAM Giri Menang Mataram H. Lalu Ahmad Zaini yang dikonfirmasi terkait kualitas air PDAM pascagempa membenarkan bahwa salah satu dampak dari gempa Lombok adalah keruhnya sumber mata air PDAM hampir di semua titik (www.cnnindonesia.com). Warga yang tidak memiliki sumur dan jauh dari sungai akhirnya harus mencari alternatif lain untuk memperoleh air layak pakai. Salah satu metode yang sederhana adalah dengan menggunakan filter air. Salah satu metode yang sedang berkembang untuk memfilter air adalah dengan melakukan penyaringan/ penjernihan menggunakan material komposit. Penggunaan dan pemanfaatan material komposit saat ini semakin berkembang, seiring dengan meningkatnya penggunaan bahan komposit yang semakin meluas mulai dari yang sederhana seperti alat-alat rumah tangga sampai sektor industri baik industri skala kecil maupun industri skala besar. Komposit mempunyai keunggulan tersendiri dibandingkan dengan bahan teknik lain karena bersifat kuat, ringan, tahan korosi dan ekonomis (Karyanik dan Sari: 2016).

Karbon aktif merupakan salah satu material yang dapat digunakan dalam pembuatan komposit, secara ilmiah pemanfaatannya pun terus dikembangkan selain sebagai bahan bakar juga dikembangkan dalam bidang pengolahan air (Fatahilah dan Ismadi Raharjo : 2007). Pemilihan material karbon aktif dikarenakan bahan baku pembuatan karbon aktif mudah didapat, murah dan karbon aktif mempunyai sifat penyerap (adsorben) yang dapat membantu pada proses penjernihan air (Fitri Afriani, dkk: 2018).

Karbon aktif merupakan suatu bahan padat yang berpori-pori dan merupakan hasil pembakaran dari bahan yang mengandung unsur karbon. Karbon aktif memiliki pori-pori yang sangat kecil sehingga karbon aktif dapat dipakai dalam proses pemurnian gas maupun cairan. Karbon aktif juga dipakai sebagai penghilang rasa dan bau serta penghilang senyawa-senyawa organik dalam air. Dengan demikian karbon aktif sangat efektif dalam proses pemurnian cairan yang telah mengandung polutan organik maupun anorganik (Kvech,dkk: 1998).

Tujuan dari kegiatan ini adalah masyarakat dapat secara mandiri membuat prototipe komposit karbon aktif (KOMAK) untuk penjernihan air, dapat meningkatkan kesadaran masyarakat akan pentingnya menjaga kebersihan lingkungan untuk mewujudkan lingkungan yang bersih dan sehat, dapat menginformasikan metode penjernihan air secara sederhana kepada warga masyarakat, masyarakat dapat menghasilkan air layak pakai dari air PDAM yang tercemar secara swadaya, serta dapat dihasilkannya kebijakan menjaga kebersihan air di tingkat masyarakat terkecil yaitu lingkup RT dan Lingkungan.

Adapun manfaat kegiatan ini adalah mendapatkan prototipe alat penjernih air berbasis komposit karbon aktif (KOMAK) yang sederhana, murah dan efisien, serta dapat membina masyarakat untuk memiliki kemampuan dan keterampilan dalam pembuatan prototipe penjernihan air sebagai upaya mengurangi limbah secara terpadu sehingga masyarakat dapat hidup pada lingkungan yang sehat dan nyaman (Darmayanti, dkk: 2014). Dari pertimbanganpertimbangan diatas maka pada pengabdian ini telah dilakukan sosialisasi penjernih air komposit karbon aktif (KOMAK) di Pagutan Barat. 


\section{ANALISIS PERMASALAHAN}

Salah satu permasalahan yang tengah dihadapi oleh masyarakat Pagutan Barat adalah masalah keruhnya air karena dampak gempa Lombok 2018 dan pengetahuan masyarakat tentang penjernihan air yang kurang. Belum adanya alat penjernih air pada akhirnya banyak masyarakat yang masih membuang limbah sembarangan dan menggunakan air sungai tanpa disaring/diolah terlebih dahulu. Dengan mempelajari analisis situasi dan pentingnya penjernihan air untuk mewujudkan lingkungan yang bersih dan sehat di lingkungan Pagutan Barat maka dapat dirumuskan permasalahan sebagai berikut :

1. Perlunya alat sederhana penjernih air yang mudah dibuat oleh masyarakat

2. Perlunya pendampingan dalam pemuatan prototipe penjernih air berbasis komposit karbon aktif (KOMAK) dan praktek penjernihan air secara sederhana menggunakan KOMAK.

\section{SOLUSI YANG DITAWARKAN}

Adapun solusi yang ditawarkan atas permasalahan diatas adalah dengan pendampingan dan pembuatan prototipe KOMAK serta memberikan pelatihan kepada masyarakat tentang bagaimana cara penjernihan air secara sederhana. Adapun prototipe alat penjernihan air menggunakan komposit karbon aktif dapat dilihat pada Gambar 1 (http://nanosmartfilter.com/teknik-penyaring-air/).

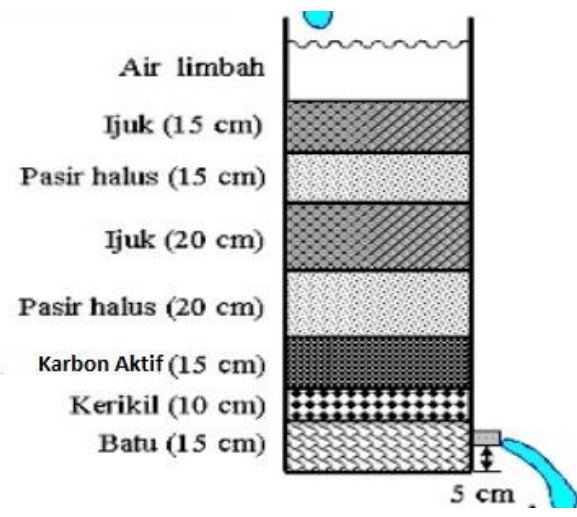

Gambar 1. Prototipe alat penjernih air menggunakan komposit karbon aktif (KOMAK) serta proses penjernihan air untuk mendapatkan air layak pakai.

Metode yang digunakan dalam pendampingan pembuatan prototipe penjernihan air menggunakan komposit karbon aktif untuk memperoleh air layak pakai ini adalah adalah Focus Group Discussion (FGD) (Ardansyah, dkk: 2016) dan pemberian bantuan teknologi berupa prototipe alat penjernih air serta praktek langsung di lapangan dalam menjernihkan air. Langkah-langkah kerja atas permasalahan dan solusi yang ditawarkan serta target luaran yang dihasilkan, tersaji dalam roadmap pada Gambar 2. 


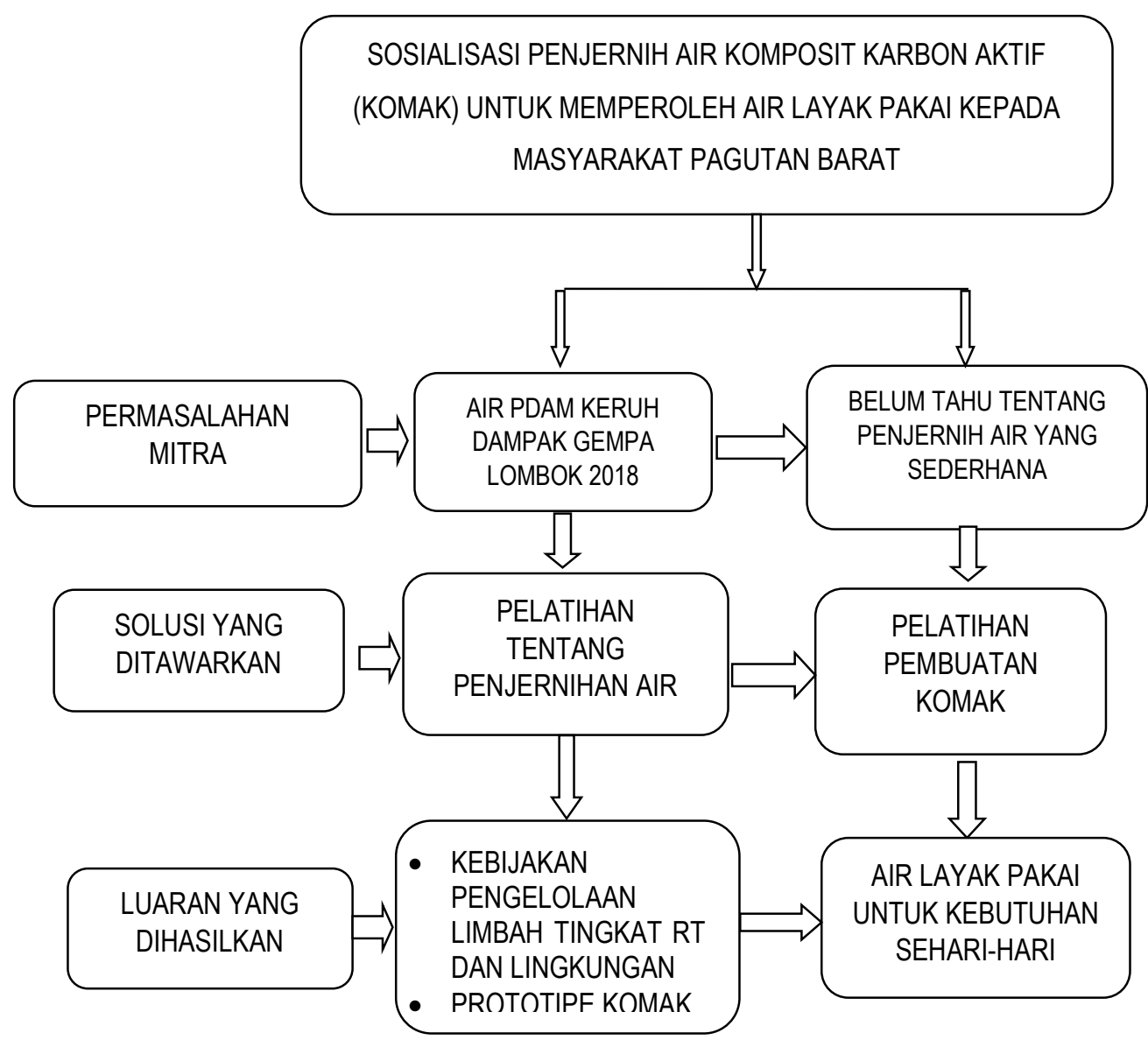

Gambar 2. Diagram roadmap pelaksanaan pengabdian kepada masyarakat.

\section{HASIL DAN PEMBAHASAN}

Pelaksanaan pengabdian pada masyarakat ini, berjalan lancar dan kondusif. Kegiatan ini dihadiri oleh warga Pagutan Barat, kota Mataram. Khalayak sasaran dalam kegiatan pengabdian pada masyarakat ini memiliki antusiasme dan dukungan yanag tinggi. Hal ini terlihat dari dukungan berupa ketersediaan tempat dan fasilitas penunjang demi kelancaran kegiatan. Para peserta antusias dan komunikatif serta aktif dalam memperhatikan presentasi dan demonstrasi tim. Adapun yang menjadi materi dalam kegiatan ini terdiri dari Manfaat Karbon Aktif dan Pentingnya filter air dan hidup sehat menggunakan air bersih.

Selain paparan materi, dalam pengabdian ini juga dilakukan penyaringan air keruh menggunakan penjernih air KOMAK dan pemberian prototipe penjernih air KOMAK kepada masyarakat. Setelah melihat secara langsung, masyarakat diajak untuk membuat penjernih air sederhana sendiri di rumah dan memperhatikan higienitas air yang digunakan untuk keperluan sehari-hari dan air minum. 


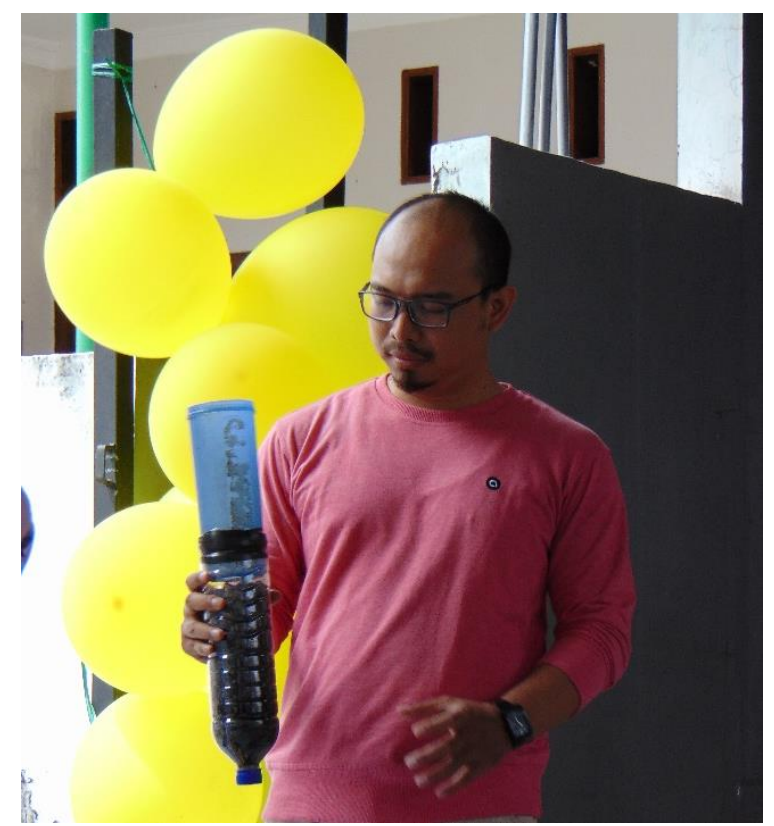

Gambar 3. Anggota pengabdian sedang mempresentasikan cara penggunaan filter air di hadapan peserta

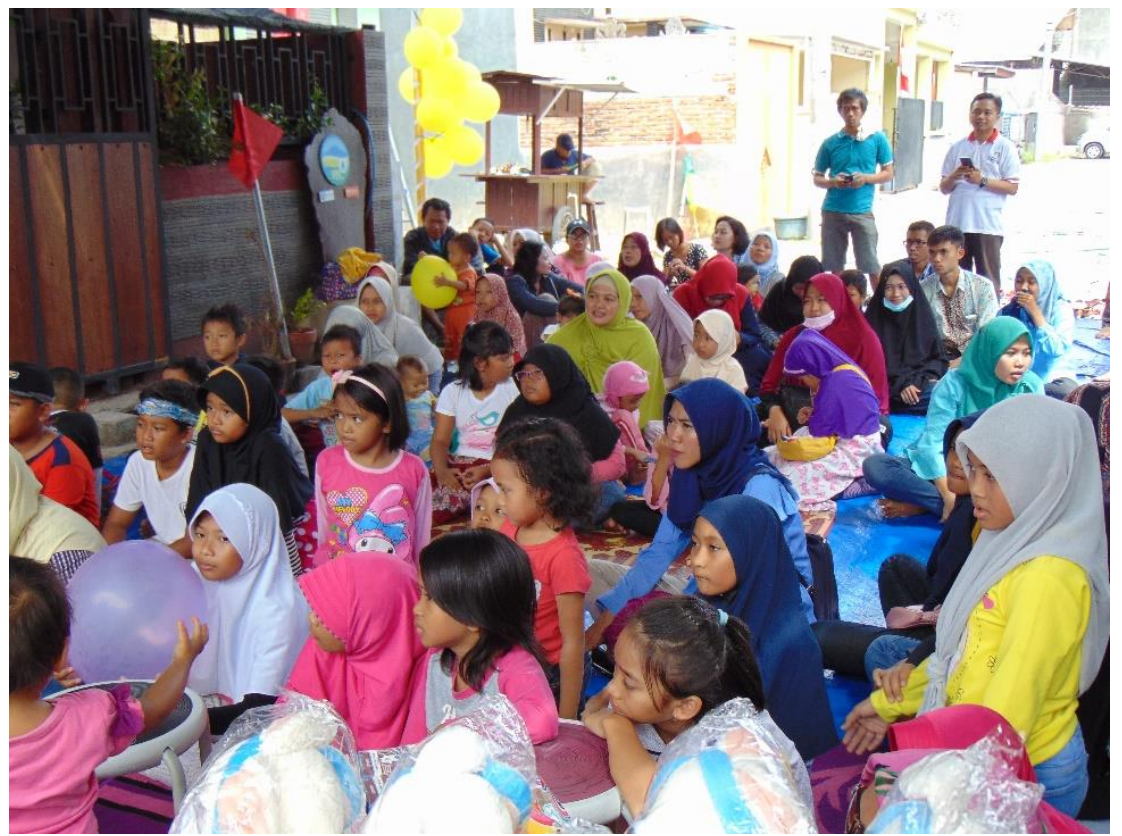

Gambar 4. Peserta bersemangat mendengarkan penjelasan pemateri dan aktif bertanya ketika sesi tanya jawab.

Pada acara sosialisasi ini terdapat beberapa faktor internal maupun eksternal yang berpengaruh terhadap pelaksanaannya. Faktor-faktor tersebut meliputi faktor pendorong dan faktor penghambat. Berikut adalah uraiannya.

\section{Faktor Pendorong}

a. Keadaan masyarakat masih ada yang memiliki air PDAM yang keruh.

b. Penyampaian presentasi yang sederhana dan menarik mampu membuat peserta untuk aktif dan akan mengaplikasikan penjernih air KOMAK dirumah masing-masing.

c. Pembuatan penjernih air yang sederhana dan murah. 


\section{Faktor Penghambat}

a. Beberapa peserta tidak fokus karena membawa balita

b. Waktu pelaksanaan workshop yang terbatas dan di hari libur ketika warga banyak yang berlibur sehingga warga berharap dilaksanakan lagi workshop sejenis.

\section{KESIMPULAN}

Kegiatan pengabdian pada masyarakat ini dirasakan sangat bermanfaat oleh warga masyarakat peserta workshop karena dapat menjadi sumber belajar, sumber inspirasi dan pengalaman terutama dalam penjernihan air dengan alat sederhana. Kegiatan ini sebaiknya sering dilakukan sebagai upaya untuk memberikan stimulus dan pemahaman kepada khalayak sasaran.

\section{UCAPAN TERIMA KASIH}

Ucapan terima kasih disampaikan kepada Lembaga Penelitian dan Pengabdian Kepada Masyarakat Universitas Mataram yang telah mendanai kegiatan ini melalui Bantuan Operasional Perguruan Tinggi Negeri (BOPTN) Tahun Anggaran 2018.

\section{REFERENSI}

Anonim. 2012. Teknik penyaring air. Didownload dari http://nanosmartfilter.com/teknik-penyaring-air/ pada tanggal 12 Juli 2019 pukul 11.18 WITA.

Ardansyah, Sapmaya Wulan, dan Hepiana Patmarina. 2016. Kegiatan focus group discussion (fgd) pengembangan strategi bisnis pada ukm sentra industri kripik di bandar lampung. Laporan Pengabdian Kepada Masyarakat didownload dari http://artikel.ubl.ac.id/index.php/PKM/article/download/681/1195 pada tanggal 12 Juli 2019 pukul 11.14 WITA.

Fatahilah dan Ismadi Raharjo. 2007. Penggunaan karbon aktif dan zeolit sebagai komponen adsorben saringan pasir cepat (sebuah aplikasi teknologi sederhana dalam proses penjernihan air bersih). JURNAL ZEOLIT INDONESIA Vol 6 No.2.

Fitri Afriani, Herman Aldila, dan Yuant Tiandho. 2018. Pengolahan air sumur di desa penyak menggunakan arang aktif tempurung kelapa dan serbuk cangkang kerang. Prosiding Seminar Nasional Penelitian \& Pengabdian pada Masyarakat. Pangkalpinang. ISBN: 978-602-61545-0-7.

Indah Nurhayati, Pungut AS, dan Sugito. 2011.pengolahan air limbah pabrik tempe dengan biofilter. Jurnal Teknik WAKTU Volume 09 Nomor 02 - ISSN : 1412 - 1867, hal 1-5.

Karyanik dan Nasmi Herlina Sari. 2016. analisis sifat mekanik material komposit ecenggondok berbahan filler ampas singkong dengan matrik polyester. Jurnal R.E.M.(Rekayasa, Energi, Manufaktur) Vol. 1. No.1. hal 1722. DOI: http://doi.org/10.21070/r.e.m.v1i1.170

Kvech, Steve, and T. Erika. 1998. Activated carbon. Departement of Civil and. Environmental Engineering. Virginia Tech University. United States of America.

Made Ganesh Darmayanti, Siti Alaa, Mala Mardialina, Wahida Hajrin. 2014. Workshop Pemilahan Sampah dan Pembuatan Kompos untuk Mewujudkan Lingkungan yang Bersih dan Sehat di Lingkungan Otak Desa Utara Ampenan. Laporan Pengabdian kepada Masyarakat Universitas Mataram.

Wishnugroho Akbar. 2018. Air pdam keruh akibat gempa, warga mataram ambil air sungai. www.cnnindonesia.com, diakses pada tanggal 11 November 2018 pukul 10.05 WITA. 